\title{
PENGEMBANGAN LAHAN SAWAH (Sawah Bukaan Baru) DAN KENDALA PENGELOLAANNYA DALAM PENCAPAIAN TARGET SURPLUS 10 JUTA TON BERAS TAHUN 2014
}

\author{
Chairul Muslim \\ Pusat Sosial Ekonomi Dan Kebijakan Pertanian. Bogor \\ Jl. A. Yani No. 70. Bogor
}

\begin{abstract}
Food is a strategic commodity, and food availability absolute priority because it can create food security and national stability. The purpose of the Director General of Food Crops is to maintain the availability of food. For 2014 the target is 10 million tons of Ministry of Agriculture surplus. In order to achieve this program certainly accompanied by inter-ministerial coordination, one with the ministry of Public Works, in order to improve the irrigation network. The purpose of this paper is to discuss the development of new wetland openings, and is limited to aspects of the development potential of land for opening new fields, as well as various technical constraints management opening new fields of socio-economic aspects. Period (19922002) wetland conversion to nonagricultural reached 110,000 ha per year. And in the time span 2007-2010, in Java, the average conversion rate of 200,000 ha per year in the form of land irrigated technical, nontechnical and dry land. New paddy fields is one form of change of use of land resources is not agricultural land into agricultural land. And targets are achieved during the period 2010 - 2014 is 2 million hectares. While the Ministry of Agriculture to plan targets new paddy fields in 2012 covering an area of 100,000 hectares (ha) outside Java. To realize the program tersbut still many obstacles that must be resolved, one of the obstacles which spatial and spatial policy in Indonesia has not had a consistent policy, and tend to overlap (vertically or horizontally). To overcome this problem one solution is the collaboration of all stakeholders, including government, private sector, researchers, farmers, and food industry players in strengthening national food security.
\end{abstract}

\section{Keywords: New Aperture Rice. Constraints Management. target}

\begin{abstract}
Abstrak: Pangan merupakan komoditas strategis, dan ketersediaan bahan pangan mutlak menjadi prioritas karena dapat menciptakan ketahanan pangan dan stabilitas nasional. Tujuan dari Dirjen Tanaman Pangan adalah mempertahankan ketersediaan bahan pangan. Untuk tahun 2014 target Kementan adalah 10 juta ton surplus beras. Agar tercapainya program ini tentunya diiringi koordinasi antar kementerian, salah satunya dengan kementerian Pekerjaan Umum, guna memperbaiki jaringan irigasi. Tujuan makalah ini adalah membahas perkembangan lahan sawah bukaan baru, dan dibatasi pada aspek potensi lahan untuk pengembangan sawah bukaan baru, serta berbagai kendala teknis pengelolaan sawah bukaan baru dari aspek sosial ekonomi. Periode (1992-2002) konversi lahan sawah ke nonpertanian mencapai 110.000 ha per tahun. Dan dalam Rentang waktu 2007-2010, di Jawa laju konversi rata-rata 200.000 ha per tahun berupa Lahan sawah beririgasi teknis, nonteknis dan lahan kering. Pencetakan sawah baru merupakan salah satu bentuk perubahan penggunaan sumberdaya lahan dari bukan lahan pertanian menjadi lahan pertanian. Dan target yang dicapai selama periode 2010 - 2014 adalah 2 juta hektar. Sedangkan rencana target Kementan untuk pencetakan sawah baru tahun 2012 seluas 100.000 hektare (Ha) di Luar Jawa. Untuk mewujudkan program tersbut masih banyak kendala yang harus segera diselesaikan, salah kendalanya yaitu tata ruang dan kebijakan tentang tata
\end{abstract}


ruang di Indonesia belum memiliki kebijakan yang konsisten, dan cenderung tumpang tindih (secara vertikal maupun horizontal). Untuk mengatasi hal tersebut salah satu solusinya adalah adanya kolaborasi semua pihak, baik pemerintah, swasta, peneliti, petani, maupun pelaku industri pangan dalam memperkuat ketahanan pangan nasional

Kata kunci : Sawah Bukaan Baru. Kendala Pengelolaan. Target

\section{PENDAHULUAN}

Perluasan areal pertanian merupakan salah satu bentuk perubahan penggunaan sumberdaya lahan (land-use change) dari bukan lahan pertanian menjadi lahan pertanian. Salah satu misi pembangunan tanaman pangan adalah mempertahankan ketersediaan bahan pangan. Bahan pangan merupakan komoditas strategis, ketersediaan bahan pangan mutlak menjadi prioritas karena dapat menciptakan ketahanan pangan dan stabilitas nasional. Salah satu Target Sukses Kementerian Pertanian bidang pertanian tanaman pangan yang tertuang dalam Rencana Strategis (Renstra) Kementerian Pertanian 2010-2014 adalah surplus beras, swasembada jagung berkelanjutan, serta swasembada kedelai pada tahun 2014.

Kementan optimis target surplus beras 10 juta ton pada tahun 2014 bisa tercapai. Untuk memenuhi target tersebut diperlukan beberapa persyaratan, diantaranya yaitu adanya perbaikan irigasi dan meredam laju konversi lahan. Untuk mendukung program tersebut adalah melakukan perluasan dan pengelolaan lahan, menurunkan konsumsi beras dan menyempurnakan manajemen dan dukungan kebijakan dan regulasi dari kementerian dan lembaga lainnya.

Pencapaian target produksi padi ke depan sangat membutuhkan dukungan irigasi yang memadai. Untuk itu Kementan berharap Kementerian Pekerjaan Umum melakukan perbaikan jaringan irigasi. Sebagaimana diketahui, berdasarkan data yang ada, prasarana irigasi di Indonesia yang masih dalam keadaan baik hanya tersisa $48 \%$ atau $3.481 .297,86 \mathrm{Ha}$ dari total irigasi di seluruh Indonesia yang mencapai 7.230.183 Ha. Jika jaringan irigasi yang rusak tersebut dibiarkan, maka kondisi pertanaman akan terganggu karena pengairan sawah tidak maksimal.

Untuk mempertahankan ketahanan pangan, tentunya perlu usaha yang dilaksanakan secara simultan (Agus dan
Mulyani, 2006): antara lain (i) pengendalian konversi lahan pertanian; (ii) mencetak lahan pertanian baru; dan (iii) intensifikasi sistem pertanian dengan menerapkan teknologi yang dapat meningkatkan produktivitas dan sekaligus mempertahankan kualitas lingkungan. Beberapa tahun belakangan ini lahan sawah yang sudah ada juga banyak yang dialih fungsikan (konversi) ke penggunaan lain, baik ke usahatani non sawah maupun ke penggunaan non pertanian. Pada hal lahan sawah bersifat irreversible dan jika tidak ada pengendalian maka cenderung progresif (Simatupang dan Irawan, 2002; Sumaryanto dan Sudaryanto, 2005).

Sisi lain bahwa dengan bertambahnya jumlah penduduk dan meningkatnya kebutuhan akan lahan untuk berbagai sektor, sangat mempengaruhi terjadinya konversi lahan yang justru mengalami peningkatan, dan di lain pihak pencetakan lahan pertanian baru (ekstensifikasi) mengalami perlambatan (Agus et al., 2006).

Dari uraian diatas makalah ini bertujuan membahas perkembangan lahan sawah dalam artian sawah bukaan baru, uraian makalah dibatasi pada aspek potensi lahan untuk pengembangan sawah bukaan baru (lahan sawah irigasi dan lahan kering), serta berbagai kendala teknis pengelolaan sawah bukaan baru dari aspek sosial ekonomi.

\section{METODE PENELITIAN}

Ditinjau dari permasalahan dan tujuan dalam tulisan ini, maka metode penelitian ini yang digunakan adalah metode deskriptif, dan untuk data kuantitatif dilakukan secara tabulasi silang.

\section{HASIL DAN PEMBAHASAN}

\section{Konversi dan Potensi Pengembangan Lahan Sawah Bukaan}

Agus dan Irawan (2006) memperkirakan bahwa tahun 2025 Indonesia akan harus mengimpor 
11,4 juta ton beras jika konversi lahan sawah berjalan secepat 190.000 ha/ tahun dan pencetakan sawah mencapai 100.000 ha/ tahun. Lahan sawah merupakan penghasil utama beras. Sebagai gambaran, pada tahun 2003 dari total luas panen sekitar 11,5 juta ha dengan produksi padi sebesar 52,1 juta ton; 49,3 juta ton padi $(94,7 \%)$ diantaranya dihasilkan dari lahan sawah dengan luas panen 10,4 juta ha dan sisanya 2,8 juta ton $(5,3 \%)$ dari lahan kering dengan luas panen 1,1 juta ha.

Konversi lahan sawah umumnya terjadi pada lahan sawah produktif ke lahan nonpertanian (pemukiman, perkotaan dan infrastruktur, serta kawasan industri). Menurut Martin Sihombing (2012) bahwa konversi lahan ke nonpertanian mencapai 110.000 ha per tahun (periode 1992-2002). Sebagian besar lahan sawah yang mengalami alih fungsi lahan sekitar 90\% terjadi di Jawa (Jawa Barat, Jojakarta dan Jawa Timur) yang diperkirakan $60 \%$ dari produksi padi nasional (Suprapto, 2000). lahan sawah yang terkonversi tersebut pada mulanya beririgasi teknis atau setengah teknis dengan produktivitas tinggi (Sumaryanto, 2001). Khudori (2012) mengemukakan juga bahwa dalam Rentang 2007-2010, di Jawa saja laju konversi rata-rata 200.000 ha per tahun berupa Lahan sawah beririgasi teknis, nonteknis dan lahan kering.

Di Jawa pada 2007 masih 4,1 juta ha,tapi kini hanya tinggal 3,5 juta ha. Lahan pertanian terancam punah.Tanpa usaha mencegah (moratorium) konversi lahan, terutama di Jawa, ketahanan pangan bakal mengalami rongrongan serius.

Selama ini sekitar 56-60\% produksi padi kita masih bertumpu pada sawah-sawah yang subur di Jawa. Dengan dukungan irigasi teknis,sawah di Jawa memiliki produktivitas yang tinggi $(51,87 \mathrm{kuintal} / \mathrm{ha})$ ketimbang sawah di luar Jawa (39,43 kuintal/ha), sehingga menghasilkan surplus beras.Selama ini, pencetakan sawah baru yang dilakukan pemerintah rata-rata hanya $37.000-45.000$ ha/tahun. Jika konversi lahan tak terkendali, surplus beras tidak akan terjadi.

Pulau Jawa semakin sulit diandalkan sebagai pemasok pangan nasional, karena: (1) alih fungsi lahan yang terus berlangsung; (2) pemenuhan kebutuhan di Jawa sendiri; dan (3) menurunnya kecukupan air untuk pertanaman padi. Menurut Las et al. ( 2000), pada tahun 2000 Pulau Jawa surplus padi 4 juta ton, namun pada tahun 2010 surplus padi diperkirakan hanya sebesar 0,26 juta ton. Sementara di luar Pulau Jawa, permintaan pangan juga terus meningkat. Dengan menurunnya laju peningkatan produksi padi, maka dalam jangka panjang produksi padi diperkirakan tidak akan mampu memenuhi permintaan, apabila konversi tetap berlanjut dan perluasan lahan pertanian tidak direalisasikan. (Tabel 1.)

Sehingga Dalam jangka panjang perluasan areal lahan sawah mutlak perlu dilaksanakan secara terkendali dan bijaksana, terutama untuk mengganti lahan sawah produktif yang dikonversi.

Tabel 1. Konversi Lahan Pertanian di Indonesia, 1983-2003

\begin{tabular}{lcccrr}
\hline Wilayah & \multicolumn{3}{c}{ Total lahan pertanian (ha) } & \multicolumn{2}{c}{ Konversi Lahan (ha) } \\
& SP 1983 1) & SP 1993 2) & SP 2003 3) & $1983-1993$ & $1993-2003$ \\
\hline Jawa & 5.442 .449 & 4.407 .029 & 4.019 .887 & -1.015 .420 & -387.142 \\
Bali \& Nusa Tenggara & 1.208 .164 & 1.060 .218 & 1.095 .551 & -147.946 & +35.333 \\
Sumatera & 5.668 .811 & 5.416 .601 & 4.249 .706 & -252.210 & -1.166 .895 \\
Sulawesi & 1.637 .811 & 1.772 .444 & 2.184 .508 & +134.693 & +412.064 \\
Kalimantan & 2.222 .153 & 2.191 .596 & 2.096 .230 & -30.557 & -95.366 \\
Maluku & 378.662 & 400.339 & 351.970 & +21.717 & -48.369 \\
Irian Jaya & 166.322 & 175.777 & 142.043 & +9.455 & -33.734 \\
Indonesia & 16.704 .272 & 15.424 .004 & 14.139 .895 & -1.280 .268 & -1.284 .109 \\
\hline
\end{tabular}

Sumber : BPS

1) sensus Pertanian Seri J3, 1983

2)sensus Pertanian Seri J3, 1993

3)sensus Pertanian Seri A3, 2003 


\section{Luas dan Sebaran Lahan Sawah Bukaan Baru}

Lahan sawah bukaan baru adalah lahan sawah yang dikonversi dari lahan kering dengan lapisan tapak bajak belum terbentuk (Didi Ardi dan Wiwik Hartatik, 2004). Lapisan tapak bajak adalah lapisan yang terbentuk di bawah lapisan olah dan terbentuk sebagai akibat adanya proses-proses oksidasi dan reduksi yang bergantian serta pelarutan atau pencucian (eluviasi) bahan-bahan kimia besi dan mangan yang kemudian diendapkan pada horizon dibawahnya (iluviasi).

Luas dan sebaran lahan sawah bukaan baru dalam kurun waktu 10 tahun terakhir (periode 1995-2005) tampaknya tidak terlalu luas. Sutomo (2004) menyatakan bahwa selama periode 1999-2002 terjadi penambahan lahan sawah di Indonesia seluas 139.302 ha, yakni terdapat di Jawa seluas 18.024 ha dan luar Jawa seluas 121.278 ha.

Rencana pencetakan sawah baru menurut Bapenas (2010) bahwa Perluasan areal pertanian merupakan salah satu bentuk perubahan penggunaan sumberdaya lahan (land-use change) dari bukan lahan pertanian menjadi lahan pertanian.

Target yang dicapai selama periode 2010 - 2014 adalah 2 juta hektar. Angka ini mencakup lahan pertanian pangan da $\mathrm{n}$ non pangan, tetapi tidak termasuk perluasan a reapertanian dari investasi swasta.

Tabel 2. Luas Rencana Pencetakan Sawah Tahun 2007

\begin{tabular}{|c|c|c|c|}
\hline \multirow[b]{2}{*}{ No } & \multirow[b]{2}{*}{ Provinsi } & \multicolumn{2}{|c|}{ Rencana 2007} \\
\hline & & $\begin{array}{c}\text { Jumlah } \\
\text { kabupaten }\end{array}$ & Luas \\
\hline 1 & NAD & 3 & 300 \\
\hline 2 & Sumatera Utara & 1 & 350 \\
\hline 3 & Sumatera Barat & 4 & 400 \\
\hline 4 & Riau & 5 & 500 \\
\hline 5 & Kepulauan Riau & 1 & 100 \\
\hline 6 & Bangka Belitung & 2 & 125 \\
\hline 7 & Jambi & 3 & 300 \\
\hline 8 & Bengkulu & 2 & 160 \\
\hline 9 & Sumatera Selatan & 4 & 850 \\
\hline 10 & Lampung & 1 & 100 \\
\hline 11 & Kalimantan Barat & 8 & 1126 \\
\hline 12 & Kalimantan Tengah & 4 & 615 \\
\hline 13 & Kalimantan Selatan & 6 & 2274 \\
\hline 14 & Kalimantan Timur & 5 & 1880 \\
\hline 15 & Sulawesi Utara & 2 & 100 \\
\hline 16 & Sulawesi Tengah & 8 & 2200 \\
\hline 17 & Sulawesi Selatan & 4 & 600 \\
\hline 18 & Sulawesi Tenggara & 8 & 1100 \\
\hline 19 & Gorontalo & 2 & 400 \\
\hline 20 & Sulawesi Barat & 4 & 1000 \\
\hline 21 & Nusa Tenggara Timur & 2 & 190 \\
\hline 22 & Nusa Tenggara Barat & 1 & 26 \\
\hline 23 & Papua & 10 & 1450 \\
\hline 24 & Papua Barat & 3 & 650 \\
\hline 25 & Maluku & 3 & 900 \\
\hline \multirow[t]{2}{*}{26} & Maluku Utara & 3 & 750 \\
\hline & Jumlah & 99 & 18446 \\
\hline
\end{tabular}


Rincian target perluasan menurut peruntukan adalah sebagai berikut:

Pencetakan sawah $\quad: 250000$ hektar

Pembukaan lahan kering : 400000 hektar

Perluasan areal hortikultura : 400000 hektar

Perluasan areal perkebunan rakyat

: 585430 hektar

Pengembangan areal hijauan makanan ternak

: 351000 hektar

Pengembangan padang penggembalaan : 13570 hektar

Berdasarkan data dari Direktorat Perluasan Areal (2007), luas lahan sawah bukan baru pada (Tabel 2). Untuk tahun 2007 Direktorat Perluasan Areal merencanakan pencetakan sawah pada 99 wilayah kabupaten seluas 18.446 ha. Data ini menunjukkan bahwa pencetakan sawah jauh lebih rendah dari alihfungsi lahan sawah ke non-pertanian. Berbagai kendala dalam perluasan sawah antara lain (i) belum tersedianya data penyebaran lahan yang potensial skala operasional (1:25.000-1:50.000); (ii) status kepemilikan lahan baik sebagai tanah adat maupun tanah negara atau kepemilikan lainnya; (iii) ketersediaan air irigasi; (iv) jumlah penduduk di wilayah potensial, dan sebagainya.

Menurut data dari PU pada 2004 terdapat potensi lahan irigasi seluas 360.000 ha yang sudah ada jaringan utama tetapi belum menjadi sawah (Direktorat Perluasan Areal, 2006a). Dari data tersebut menunjukkan adanya peluang untuk perluasan sawah karena telah tersedia sarana irigasinya.

Menurut data dari PU pada 2004 terdapat potensi lahan irigasi seluas 360.000 ha yang sudah ada jaringan utama tetapi belum menjadi sawah (Direktorat Perluasan Areal, 2006a). Dari data tersebut menunjukkan adanya peluang untuk perluasan sawah karena telah tersedia sarana irigasinya.

\section{Kriteria Kesesuaian lahan Sawah}

Sawah bukaan baru dapat didefinisikan dari dua aspek: (i) Waktu sejak sawah tersebut dicetak. Biasanya sawah yang dicetak dalam 10 tahun terakhir dikategorikan sebagai sawah bukaan baru. (ii) Sifat tanah sawah bukaan baru. Sawah bukaan baru dicirikan oleh belum terbentuknya lapisan tapak bajak, sehingga penggunaan airnya relatif boros.
Sawah bukaan baru yang berasal dari Mollisols relatif cepat membentuk lapisan tapak bajak dan sebaliknya yang berasal dari Oxisols atau Ultisols dengan agregat mantap, akan sulit membentuk lapisan tapak bajak.

Untuk pembukaan lahan sawah baru diperlukan beberapa persyaratan teknis (terutama biofisik) dan non-teknis. Persyaratan teknis atau biofisik meliputi beberapa parameter, yaitu: (a) topografi: elevasi dan lereng; (b) Iklim, terutama ketersediaan air; (c) keadaan tanah: drainase, tekstur, kedalaman tanah, sifatsifat kimia (KTK, salinitas, alkalinitas, pirit); (d) bahaya banjir; dan (e) penggunaan lahan.

Kriteria untuk lahan sawah tersebut sebagian besar mengacu pada Juknis Evaluasi Lahan (Djaenudin et al., 2003). Elevasi atau ketinggian tempat di atas permukaan laut dibatasi sampai dengan $700 \mathrm{~m}$ dpl. karena berkaitan dengan radiasi matahari. Pada daerah dataran tinggi dengan elevasi $>700 \mathrm{~m}$ dpl., radiasi matahari dan suhu udara relatif rendah proses fotosintesis menjadi lambat, sehingga tanaman padi yang sesuai adalah yang berumur panjang.

Faktor iklim atau sumber air merupakan faktor pendukung utama dalam usaha tani lahan sawah. Persyaratan dalam pembukaan lahan sawah harus tersedia sumber air berupa waduk/dam, bendungan, dan sungai. Jika tidak tersedia sumber air tersebut, maka kondisi iklim khususnya curah hujan disyaratkan tergolong cukup basah yaitu tipe agroklimat A atau B menurut kriteria Oldeman (1980). Hal yang sangat penting adalah Faktor tanah yang dipertimbangkan sebagai karakteristik lahan pada tanah-tanah mineral adalah drainase, tekstur tanah, dan kedalaman tanah. Sedangkan untuk tanah gambut berdasarkan ketebalan dan tingkat kematangannya. Demikian pula tanah-tanah rawa yang mengandung pirit, kedalaman pirit harus dipertimbangkan sebagai salah satu parameter. Demikian juga Faktor salinitas dan alkalinitas tanah, baik pada tanahtanah di daerah pesisir pantai maupun tanah-tanah lainnya yang berkadar garam tinggi. 


\section{Potensi Pengembangan lahan Sawah Bukaan Baru}

Potensi pengembangan lahan untuk sawah irigasi dan alternatif penggunaan lainnya, seperti sawah rawa, tanaman pangan lahan kering dan tanaman perkebunan, sangat ditentukan oleh hasil evaluasi lahan. Dalam evaluasi lahan untuk sawah irigasi yang perlu dipertimbangkan adalah kualitas lahan ("land quality") karena berpengaruh terhadap produktivitas sawah irigasi, seperti ketersediaan air, tekstur tanah, laju infiltrasi setelah pelumpuran, retensi dan ketersediaan hara, toksisitas, dan keadaan terrain (Center for Soil Research/FAO, 1983; Hardjowigeno et al., 1994).

Ada 5 aspek lain yang harus dipertimbangkan, dalam pencetakan sawah baru yaitu: (1) status penguasaan, (2) wilayah administrasi (lokasi), (3) Keteresediaan tenaga kerja, dan (4) keetersediaan infrastruktur untuk pengadaan input dan penyaluran output usahatani, dan (5) peluangnya untuk dikonversi menjadi lahan pertanian dalam kaitannya dengan rencana tata ruang (peruntukan lahan untuk pengembangan pemukiman, perkotaan, konservasi hutan, dan lain-lain). Luas lahan potensial untuk perluasan areal adalah dari luas lahan hasil pemetaan kesesuaian lahan untuk pertanian. Kelima faktor tersebut bermanfaat untuk meletakkan asumsi yang dipergunakan dalam membuat perkiraaan tentang potensi ketersediaan lahanyang potensial untuk perluasan areal pertanian. Untuk melihat berapa luas lahan yang potensial untuk pengembangan atau perluasan areal lahan sawah di masa depan, akan dibandingkan antara data luas lahan yang sesuai dengan data penggunaan lahan yang ada saat ini.

Potensi lahan sawah diperoleh dari peta arahan tata ruang pertanian yang disusun oleh Puslitbangtanak (2006) skala 1:250.000 pada 20 provinsi dan Puslitbangtanak (2002) skala 1:1.000.000 untuk provinsi lainnya. Data penggunaan lahan yang digunakan berskala 1:250.000 bersumber dari Badan Pertanahan Nasional (2000-2002), Bakosurtanal (2003) dan Puslitbangtanak (2002; 2003). Kedua data spasial tersebut, yakni data potensi lahan dan penggunaan lahan ditumpang tepatkan (overlay) untuk mendapatkan lahan-lahan yang masih tersedia untuk pengembangan atau perluasan areal persawahan.

Lahan-lahan potensial digolongkan tersedia apabila penggunaan lahannya belum digunakan untuk pertanian maupun penggunaan lainnya yang bersifat permanen, yaitu berupa belukar atau hutan yang dapat dikonversi. Dari hasil overlay tersebut, selanjutnya dikalikan dengan suatu faktor koreksi sebesar 0,7 dengan asumsi bahwa sebesar $0,3(30 \%)$ dari lahan tersebut tidak sesuai dan sudah digunakan untuk berbagai macam penggunaan namun tidak dapat didelineasi dalam peta skala 1:250.000 yang digunakan. Potensi ketersediaan lahan sawah dibedakan antara lahan rawa dan non-rawa sesuai dengan agroekosistemnya.

\section{Potensi Perluasan Areal Pertanian Sawah (la han basah)}

Hasil pemetaan kesesuaian lahan yang dilakukan oleh Pusat Penelitian Tanah dan Agriklimat, badan Penelitian dan pengembangan Pertanian tahun 2000 memperoleh kesimpulan bahwa luas lahan yang secara agroklimat sesuai untuk usahatani lahan sawah adalah sekitar 24,5 juta hektar. Dari jumlah tersebut yang ada sekarang ini telah dimanfaatkan adalah seluas 8,5 juta hektar. Dengan demikian terdapat sekitar 16 juta hektar yang menurut sudut pandang kesesuain adalah potensial untuk dikembangkan menjadi lahan sawah (Mulyani dan Agus, 2006). Lahan potensial ini mencakup lahan rawa/pasang surut dan non rawa /pasang surut.

Untuk jangka menengah, meskipun luas total lahan potensial di atas sangat besar, namun yang dapat didayagunakan untuk perluasan lahan sawah diperkirakan hanya kurang dari 25 persen. Hal ini terkait dengan lokasi, ketersediaan infrastruktur dan tenaga kerja pertanian yang tersedia di lokasi yang bersangkutan. Sebagian besar lahan tersebut terletak di pulau-pulau besar di luar Jawa yaitu di papua dan maluku, sumatera, kalimantan, dan sulawesi. Meskipun relatif kecil luasannya, potensi lahan di pulau jawa masih tersedia.

Potensi alamiah terbesar adalah di Papua (dan Maluku). Total lahan yang sesuai untuk dijadikan sawah adalah sekitar 8 juta hektar. Namun, mengingat ketersediaan infrastruktur dan tenaga kerja di wilayah 
tersebut masih rendah, maka untuk jangka menengah luas yang cukup realistis untuk didayagunakan menjadi lahan sawah diperkirakan hanya sekitar 1 persen atau sekitar 80 ribu hektar. (Bappenas, 2010).

Potensi kedua terbesar adalah di Pulau Sumatera, yang diperkirakan seluas 3,9 juta hektar kesesuaian lahan cukup potensial untuk didayagunakan menjadi lahan sawah yang terdiri atas lahan rawa/pasang surut seluas 1,9 juta hektar dan non rawa 2 juta hektar. Dibandingkan dengan kondisi di Papua, tingkat ketersediaan infrastruktur dan tenaga kerja di pulau Sumatera pada umumnya lebih baik.

Oleh karena itu, persentase luas lahan yang layak dikategorikan potensial juga lebih tinggi dari pada yang ada di Papua. Apabila diasumsikan pangsa luas lahan dalam jangka menengah layak dikategorikan potensial untuk perluasan areal di wilayah pasang surut adalah sebesar 5 persen, sedangkan di wilayah non pasang surut adalah sebesar 10 persen, maka potensi perluasan areal sawah di sumatera diperkirakan seluas 295 ribu hektar, yang terdiri atas lahan rawa/pasang surut sekitar 95 ribu hektar dan lahan non rawa/pasang surut sekitar 200 ribu hektar.

Perluasan areal $\mathrm{p}$ [ertanian untuk usahatani sawah tidak semata-mata dari lahan yang belum didayagunakan. Secara empiris, perluasan areal baku sawah dilakukan dengan cara mencetak lahan sawah baru dari sebelumnya lahan tidur (tanah terlantar), hutan yang dapat dikonversi (APL), dan lahan kering yang sebelumnya berupa lading atau kebun. Namun sebaliknya perlu diingatkan pula bahwa sebagian dari lahan sawah yang telah ada juga tidak sedikit yang beralih fungsi menjadi areal pertanian lahan kering, bahkan menjadi lahan non pertanian.

\section{Potensi Perluasan Areal Pertanian Lahan Kering}

Dari sudut pandang agronomi, persyaratan untu $\mathrm{k}$ perluasan areal pertanian lahan kering relatif lebih longgar dari pada lahan sawah. Dapat disimpulkan bahwa hampir semua lahan yang secara agroklimat sesuai untuk dijadikan sawah, relatif lebih longgar dari pada lahan sawah. Pengembangan pertanian lahan kering tidak memerlukan fasilitas irigasi sebaik lahan sawah. Dapat disimpulkan bahwa hampir semua lahan yang secara agroklimat sesuai untuk di jadikan sawah. Namun sebaliknya persoalan utamanya adalah pemilihan jenis komoditas yang sesuai. Dari sudut pandang sosial ekonomi pada umumnya persyaratan untuk pengembangan usahatani lahan kering juga lebih longgar terkecuali untuk uasahatani hortikultura benilai ekonomi tinggi.

\section{TARGET PENCETAKAN SAWAH BARU (realisasi dan kendala)}

\section{Rencana Kementan tahun 2012 pencetakan sawah baru}

Kementerian Pertanian berencana pada tahun 2012 akan membuka lahan pertanian seluas 100.000 hektare (Ha) di Luar Jawa. Begitu pula dengan gerakan proberas untuk memanfaatkan lahan sawah milik warga yang kurang produktif', bahwa proyek pembukaan lahan baru ini direncanakan akan selesai pada tahun ini dan keseluruhan hamparan sawah baru tersebut sudah dapat dicetak dan ditanami. Pencetakan sawah baru ini diharapkan akan mampu merealisasikan target surplus produksi beras nasional yang mencapai 10 juta ton tahun 2014. Pembukaan lahan ini akan diratakan dibeberapa wilayah di luar Pulau Jawa. Hal ini dimaksudkan untuk menjaga kesuburan lahan di Indonesia. Peningkatan produksi pasti berkaitan dengan kesuburan lahan, oleh karena itu program ini diintensifkan ke lahan marginal yang banyak terdapat di luar Pulau Jawa. Untuk merealisasikan program ini, pemerintah telah menyiapkan anggaran dana sebesar Rp 9 triliun. Dana ini rencananya digunakan untuk membuka lahan baru di daerah Kalimantan Timur, seperti di Kabupaten Paser, Kutai Barat, Kutai Timur, Bulungan, Berau dan Nunukan. Pemakaian dana tersebut meliputi untuk biaya pembukaan lahan, pembangunan infrastruktur seperti jalan sebagai akses menuju dan dari lahan baru tersebut, dan pemberian insentif kepada petani.

\section{Kendalanya}

Masalah yang akan muncul yakni dari sisi hukum, kelembagaan, maupun ketersediaan data dan informasi. Lahan pertanian hanya dapat diwujudkan apabila perencanaan tata ruang baik secara nasional maupun wilayah telah disepakati. Namun sampai saat ini, tata 
ruang dan kebijakan tentang tata ruang di Indonesia belum memiliki kebijakan yang konsisten, dan cenderung tumpang tindih (secara vertikal maupun horizontal). UU Lahan Pertanian Pangan Abadi diaharapkan dapat menjadi payung hukum untuk menjamin lahan yang cukup untuk memproduski pangan terutama beras yang merupakan pangan pokok masyarakat

Kendala lainnya akan dihadapi dalam menjalankan proyek ini adalah seiring dengan peningkatan jumlah pemduduk dan perkembangan struktur ekonomi, kebutuhan lahan untuk kegiatan nonpertanian cenderung terus meningkat. Kecenderungan alih fungsi lahan tersebut harus diiringi usaha pencegahan konversi atau alih fungsi lahan pertanian menjadi nonpertanian.

Hal terpenting dari realisasi program ini adalah adanya bentuk kerjasama yang baik antara pemerintah, swasta, BUMN, peneliti, dan tentunya petani. Petani harus dilibatkan dalam proyek ini agar mereka juga sadar akan kebutuhan lahan pertanian abadi. Selain itu, program ini dapat meningkatkan pendapatan petani sehingga akan menyejahterakan kehidupan petani dan pertanian akan menjadi soko guru perekonomian Indonesia. Strategi untuk melakukan intensifikasi lahan pertanian dan diversifikasi pangan juga harus gencar dilaksanakan agar dapat mengurangi konsumsi beras nasional sehingga Indonesia swasembada beras dan surplus beras.

Adanya pembukaan sawah baru ini dapat dilakukan dengan partisipasi berbagai pihak terutama petani. Konversi lahan harus dipantau dan dicegah agar program ini tidak sia-sia. Hal yang paling penting dari semua ini adalah kembali ke tujuan awalnya yakni menjaga kesuburan lahan. Program pertanian yang dijalankan tentunya harus menjaga keberlanjutan ekosistem di lingkungan tersebut. Peningkatan produktivitas tidak semena-mena harus merusak alam dengan cara teknik pertanian yang salah.

\section{Upaya solusi pencetakan Sawah Baru}

Cetak sawah baru sebaiknya tidak menargetkan produktivitas yang maksimal karena merupakan lahan baru dibuka, salah satunya kadar keasaman yang masih tinggi sehingga mempengaruhi produktivitas padi. Sisi lain adalah dalam dua sampai tiga tahun ke depan produktivitasnya baru dapat dilihat maksimal, bisa mencapai empat sampai lima ton per hektar. Namun untuk lahan sawah yang baru ini masih di bawah standar, asumsi untuk produktivitas pada kisaran 2,5 ton sampai tiga ton per hektar. Sedangkan untuk peningkatan Produktivitas padi tidak hanya bergantung pada lahan, tetapi juga ketersediaan air, kesuburan lahan, dukungan penyuluh, dukungan modal, dan sarana produksi. Untuk mengatasi pencetakan sawah baru ada beberapa kriteria solusi yang nampaknya dapat mengatasi permasalahan pencetakan sawah bukaan baru, Jika program ini benar-benar akan direalisasikan, upaya yang mungkin dapat dipertimbangkan ialah, pertama lahan yang dibuka bukanlah hutan atau area vital konservasi alam namun lahan-lahan marginal yang potensial atau lahan rusak yang tidak dimanfaatkan lagi, kedua teknik pertanian yang dipakai diusahakan merupakan pertanian organik agar tetap menjaga kesuburan lahan seperti tujuan awalnya, ketiga intensifikasi lahan dengan cara bertanam polikultur atau dengan kata lain tidak hanya bertanam padi karena pertanian monokultur dan terus menerus juga dapat merusak lahan, dan keempat peran serta petani harus benar-benar diutamakan agar program ini bukan justru menyengsarakan petani melainkan menyejahterakan petani Indonesia.

Hal lain upaya mengatasi pencetakan sawah terutama lahan yang berbentuk terasering yang umumnya menggunakan teras bangku dengan galengan diyakini dapat mengurangi laju erosi melalui pengurangan aliran permukaan dan kehilangan unsur hara. Menurut Kurnia dan Suwardjo (1985), teras bangku pada tanah bersolum dalam merupakan cara terbaik untuk mencegah erosi pada lahan sampai lereng $10 \%$. Pada lahan sawah, erosi terjadi pada saat pengolahan tanah. Erosi yang terjadi paling kecil sebesar 1-4 t/ha/tahun pada lahan berlereng sampai $8 \%$, sehingga dapat mengurangi kehilangan lapisan atas tanah dan pencucian unsur hara (Sutono et al., 2001).

Teknik konservasi tanah dan cara-cara pencegahan erosi terbukti dapat mengurangi jumlah hara yang hilang dari dalam tanah. Pencetakan lahan sawah irigasi membutuhkan investasi yang besar. Oleh karena itu, alih fungsi lahan sawah perlu dihindarkan. Sekali 
lahan sawah beralih fungsi, hampir dapat dipastikan lahan tersebut tidak akan kembali lagi menjadi lahan sawah. Oleh karena itu, lahan sawah irigasi dan juga lahan sawah nonirigasi lainnya perlu ditetapkan sebagai lahan sawah abadi yang dilindungi undangundang dengan sanksi hukum yang tegas.

\section{KESIMPULAN DAN SARAN}

\section{Kesimpulan}

Salah satu misi pembangunan tanaman pangan adalah mempertahankan ketersediaan bahan pangan. Untuk dapat menciptakan ketahanan pangan dan stabilitas nasional. Target Sukses Kementerian Pertanian bidang pertanian tanaman pangan diantaranya adalah surplus beras. Untuk mendukung program tersebut adalah melakukan perluasan dan pengelolaan lahan.

Untuk terlaksananya target surplus beras adalah dengan program pencetakan sawah baru yang dilakukan pemerintah baru pada tahap rata-rata hanya $37.000-45.000$ ha/tahun, atau secara nasional penambahan lahan sawah di Indonesia seluas 139.302 ha. Rencana target yang dicapai selama periode 2010 - 2014 adalah 2 juta ha. Pencetakan sawah baru ini masih tahap perencanaan di seluruh wilayah seluas 18.446 ha.

Potensi pengembangan lahan untuk sawah bukaan baru adalah sawah rawa, tanaman pangan lahan kering dan tanaman perkebunan. Potensi perluasan areal lahan basah sekitar 24,5 juta hektar, dan potensi untuk pencetakan sawah di lahan kering lebih mudah karena secara agroklimat sesuai untuk dijadikan sawah, relatif lebih longgar dari pada lahan sawah.

Target rencana tahun 2012 pencetakan sawah baru seluas 100.000 hektare (Ha) di Luar Jawa.

dan keseluruhan hamparan sawah baru tersebut sudah dapat dicetak dan ditanami, dan diharapkan akan mampu merealisasikan target surplus produksi beras nasional yang mencapai 10 juta ton tahun 2014.

\section{Saran}

Untuk mewujudkan program cetak sawah tetntunya ada kolaborasi semua pihak, baik pemerintah, swasta, peneliti, petani, maupun pelaku industri pangan dalam memperkuat ketahanan pangan nasional. Tidak efektifnya peraturan yang telah ada dapat diperbaiki dengan:

1. Memperkuat sistem administrasi tanah;

2. Meningkatkan koordinasi antar lembaga terkait

3. Sosialisasi mekanisme implementasi tata ruang wilayah sampai ke tingkat masyarakat.

4. Selain itu, diperlukan strategi yang tepat dalam mewujudkan pencetakan lahan sawah baru yakni pertama peningkatan insentif berupa pendapatan tambahan bagi petani. Kemudian strategi kedua, jangan under estimate kerugian akibat alih fungsi lahan sawah, ketiga, diversifikasi pangan pengganti beras dan keempat, regulasi untuk melindungi lahan-lahan pertanian produktif.

\section{DAFTAR PUSTAKA}

Agus dan Irawan. 2006. Agricultural land conversion as a threat to food security and environmental quality. Jurnal Penelitian dan Pengembangan Pertanian 25(3): 9098.

Agus dan Mulyani. 2006. Judicious use of land resources for sustaining Indonesian rice self sufficiency. Rice Industry, Culture and Environment, Book 1. Indonesian Center for Rice Research, Sukamandi, Indonesia.

Agus, F., I. Irawan, H. Suganda, W. Wahyunto, A. Setyanto, and M. Kundarto. 2006. Environmental multifunctionality of Indonesian agriculture. Jurnal: Paddy Water Environment 4: 181-188.

Bapenas. 2010. Rencana Kebijakan Strategis Perluasan Areal Pertanian Baru.

Center for Soil Research/FAO, 1983. Reconnaissance Land Resource Surveys, 1: 250.000 Scale, Atlas Format Procedure. AGOF/INS/78/006. Manual 4, Version 1. UNDP/FAO, CSR, Bogor. 106 p. dalam Hasil Round Table II Pengendalian Konversi dan Pengembangan Lahan Pertanian. Direktorat Perluasan Areal, Ditjen Bina Produksi Tanaman Pangan, Departemen Pertanian, Jakarta. Dalam Rangka 
Mendukung Prioritas Nasional Ketahanan Pangan. Direktorat Pangan Dan Pertanian Kementerian Perencanaan Pembangunan Nasional/Badan Perencanaan Pembangunan Nasional (BAPPENAS).

Djaenudin, D., Marwan H., Subagyo H., dan A. Hidayat. 2003. Petunjuk Teknis untuk Komoditas Pertanian. Edisi Pertama tahun 2003, ISBN 979-947425-6. Balai Penelitian Tanah, Pusat Penelitian dan Pengembangan Tanah dan Agroklimat, Badan Litbang Pertanian.

Hardjowigeno, S., N. Suharta, D. Djaenudin, D. Marsoedi, J. Dai, H. Basuni, V. Suwandi, Widagdo, L. Hakim, S. Bachri, dan E.R. Jordens. 1994. Evaluasi lahan untuk irigasi. Laporan Teknis No. 8. Versi 1.0. LREP II, Pusat Penelitian Tanah dan Agroklimat, Bogor. $10 \mathrm{hlm}$.

Khudori. 2012. Konversi Lahan Pertanian. Anggota Pokja Ahli Dewan Ketahanan Pangan Pusat, Pegiat Asosiasi Ekonomi Politik Indonesia (AEPI).

Kurnia, U. dan H. Suwardjo. 1985. Pengaruh beberapa cara konservasi mekanik terhadap erosi pada tanah Tropudalfs dan Troporthents di Yogyakarta. Pemberitaan Penelitian Tanah dan Pupuk 4: 46-50.Suwardjo.1985.

Las, I., S. Purba, B. Sugiharto, dan A. Hamdani. 2000. Proyeksi kebutuhan dan pasokan pangan tahun 2000-2020. Pusat Penelitian Tanah dan Agroklimat. Bogor.

Martin Sihombing.2012. RUU Lahan Pertanian Abadi diprioritaskan ; Konversi lahan pertanian semakin merisaukan. Bisnis Indonesia.

Mulyani, A. dan F. Agus. 2006. Potensi Laha $n$ Mendukung Revitalisasi Pertanian. Dala m A. Dariah, N.L. Nurida, Irawan, E. Hus en, F. Agus (eds). Mulfifungsi dan Revital isasi ertanian. Prosiding Seminar. Badan Penelitian dan Pengembangan Pertanian bekerjasama dengan Ministry of Agriculture, Forestry and Fisheries - Japan , dan ASEAN Secretariat., Jakarta.

Oldeman.1980. The agro-climatic classification of rice growing environment in Indonesia. in: Proceedings of a symposium on the agrometeorology of the rice crop (WMOjIRRl), Los Banos, 47 - 55.

Puslitbangtanak. 2002. Atlas Pewilayahan Komoditas Pertanian Unggulan Nasional, skala 1:1.000.000. Puslitbangtanak, Bogor.

Puslitbangtanak. 2003. Arahan Lahan Sawah Utama dan Sekunder Nasional di P. Jawa, P. Bali dan P. Lombok. Laporan Akhir Kerjasama antara Pusat Penelitian dan Pengembangan Tanah dan Agroklimat, Badan Litbang Pertanian dengan Proyek Koordinasi Perencanaan Peningkatan Ketahanan Pangan, Biro Perencanaan dan Keuangan, Sekretariat Jenderal Departemen Pertanian.

Simatupang dan Irawan, 2002.

Pengendalian konversi lahan pertanian:Ti njauan ulang kebijakan lahan pertanian abadi. Makalah Seminar Nasional Multifungsi dan Konversi Lahan Pertanian , 25 Oktober 2002. Badan Litbang Deptan. Jakarta.

Sumaryanto dan T. Sudaryanto. 2005. Pemahaman Dampak Negatif Konversi Lahan Sawah Sebagai Landasan Perumusan Strategi Pengendaliannya. Makalah dipresentasikan dalam Seminar Penanganan Konversi Lahan dan Pencapaian Lahan Pertanian Abadi yang diselenggarakan oleh Kerjasama Kantor Kementerian Koordinator Bidang Perekonomian dengan Pusat Studi Pembangunan Pertanian dan Pedesaan (PSP3 - LPPM IPB) di Jakarta, 13 Desember 2005.

Sumaryanto. 2001. Konversi lahan sawah ke penggunaan nonpertanian dan dampak negatifnya. hlm. 1-18 dalam Prosiding Seminar Nasional Multifungsi Lahan Sawah. Bogor, 1 Mei 2001. Pusat Penelitian dan Pengembangan Tanah dan Agroklimat, Bogor.

Suprapto. (2000). Land and Water Resources Development in Indonesia. Director General Agriculture Infrastructure Minister of Agriculture, Indonesia. http://www.fao.org/ docrep/005/ac623eog.htm. 
Chairul Muslim : Pengembangan Lahan Sawah (sawah Bukaan Baru) ...

Sutomo, S. 2004. Analisa data konversi dan prediksi kebutuhan lahan. hlm. 135149.

Sutono, S., H. Kusnadi, dan M.S. Djunaedi. 2001. Pendugaan erosi pada lahan sawah dan lahan kering Sub DAS Citarik dan
DAS Kaligarang Dalam F. Agus (Ed.). Prosiding Seminar Nasional Multifungsi Lahan Sawah. Pusat Penelitian dan Pengembangan Tanah dan Agroklimat, Bogor. hlm. 79-92. 